\title{
Parasitism Capacity of Trichogramma pretiosum and Trichogramma acacioi (Hym.: Trichogrammatidae) on Eggs of Sitotroga cerealella (Lep.: Gelechiidae)
}

\author{
Dirceu Pratissoli ${ }^{1}$, José Cola Zanuncio ${ }^{2 *}$, Ulysses Rodrigues Vianna ${ }^{2}$, Josimar Souza \\ Andrade $^{2}$, Fernando Domingo Zinger ${ }^{1}$, João Rafael de Conte Carvalho de Alencar ${ }^{1}$ and \\ Germano Leão Demolin Leite ${ }^{3}$ \\ ${ }^{I}$ Departamento de Fitotecnia; Centro de Ciências Agrárias; Universidade Federal do Espírito Santo; \\ dirceu@npd.ufes.br; 29500-000, Alegre - ES - Brasil. ${ }^{2}$ Departamento de Biologia Animal; Universidade Federal de \\ Viçosa; zanuncio@ufv.br; 36571-000, Viçosa - MG - Brasil. ${ }^{3}$ Núcleo de Ciências Agrárias; Universidade Federal \\ de Minas Gerais; gldleite@ufmg.br; 3404-006; Montes Claros - MG - Brasil.
}

\begin{abstract}
The objective of this work was to evaluate the parasitism capacity of Trichogramma pretiosum Riley and T. acacioi Brun, Moraes and Soares (Hymenoptera: Trichogrammatidae) in eggs of the alternative host Sitotroga cerealella (Olivier) (Lepidoptera: Gelechiidae) aiming to use both species in biological control programs of Nipteria panacea Tierry-Mieg (Lepidoptera: Geometridae). The parasitism rhythm and total parasitism of these parasitoid species were affected by the temperature with higher values during the first $24 \mathrm{~h}$ of their life. Parasitism period was longer for $\mathrm{T}$. pretiosum and $\mathrm{T}$. acacioi at the lowest temperature.
\end{abstract}

Key words: Avocado, Insecta, Trichogrammatidae, Temperature

\section{INTRODUCTION}

The use of Trichogramma spp. parasitoids in programs of biological control of Nipteria panacea Tierry-Mieg (Lepidoptera: Geometridae) is promising because two species of this genus have been found parasitizing eggs of this pest in field conditions (Pratissoli and Fornazier, 1999). The study of parasitism capacity before the species can be released in biological control programs is an important step (Oliveira et al., 2000; Pratissoli et al., 2004a; Pratissoli et al., 2004c; Soares et al., 2007). Daily parasitism and parasitism period of
Trichogramma may vary among the species, lineage, host, temperature and climatic conditions (Pratissoli et al., 2004a; Pratissoli et al., 2004c; Oliveira et al., 2005). Many species of this genus present maximum fecundity around $25^{\circ} \mathrm{C}$ with decreasing values at extreme temperatures (Pratissoli et al., 2004b; Pratissoli et al., 2005a).

The objective of this study was to evaluate the parasitism capacity of Trichogramma pretiosum Riley and T. acacioi Brun; Moraes; Soares (Hymenoptera: Trichogrammatidae) in the eggs of the alternative host Sitotroga cerealella (Olivier)

Author for correspondence 
(Lepidoptera: Gelechiidae) in order to use them in biological control programs of $N$. panacea.

\section{MATERIALS AND METHODS}

The study was carried out at the Laboratory of Entomology of the "Centro de Ciências Agrárias" of the "Universidade Federal do Espirito Santo" in the Municipality of Alegre, Espirito Santo State, Brazil. Individuals of these parasitoids were obtained in commercial avocado crops in eggs of $N$. panacea. The parasitism capacity was evaluated in climatic chambers at RH $70 \pm 10 \%, 14 \mathrm{~h}$ photophase and temperatures of $15,20,25,30$, and $35 \pm 2^{\circ} \mathrm{C}$.

Recently emerged $T$. acacioi and $T$. pretiosum females obtained from eggs of $S$. cerealella were individualized in Duran glass tubes with droplets of pure honey in its internal wall. A blue cardboard $(3.5 \times 0.5 \mathrm{~cm})$ with 40 eggs of the host were glued with arabic gum at 5\% and offered to each parasitoid female during $24 \mathrm{~h}$. The cardboards were daily changed until the death of parasitoid females. They were individualized in polyethylene bags and reared in acclimatized chamber at temperatures previously mentioned.

The experiment was developed in randomized design with 5 treatments and 20 repetitions consisting of a parasitoid female and the data submitted to a variance analysis. The averages were compared with Tukey test at 5\% probability level.

\section{RESULTS AND DISCUSSION}

Parasitism of T. pretiosum and T. acacioi varied with temperature during the first $24 \mathrm{~h}$ and increasing between 15 to $25^{\circ} \mathrm{C}$. T. pretiosum and T. acacioi presented higher parasitism rate in the first days of their life at all temperatures (Fig.s 1 and 2).
This agreed with results of increasing daily parasitism rate of $T$. pretiosum between 18 to $25^{\circ} \mathrm{C}$ in eggs of Tuta absoluta (Meyrick) (Lepidoptera: Gelechiidae) and from 18 to $32^{\circ} \mathrm{C}$ with Plutella xylostella (L.) (Lepidoptera: Plutellidae) (Pratissoli et al., 2004a).Parasitism period was longer at lower temperatures and $T$. pretiosum presented higher parasitism rate than T. acacioi (Fig. 1 and 2).

Accumulated parasitism also varied with temperature. T. pretiosum presented $80 \%$ of parasitism at seven, one, two, one and one days at $15,20,25,30$ and $35^{\circ} \mathrm{C}$ (Fig. 1) while this was registered at days three, two, two, two and one for $T$. acacioi at these temperatures respectively (Fig. 2). Longer longevity of $T$. pretiosum (22 days) and T. acacioi (8 days) at temperature similar to their thermal inferior limits confirmed the reports of these species being collected at altitudes near $1.000 \mathrm{~m}$. However, T. pretiosum presented an inverse relationship between longevity and temperature increase which indicated that the effect of this parameter varied with Trichogramma species (Maceda et al. 2003; Pratissoli et al., 2004b; Pratissoli et al., 2005b). Parasitism potential of $T$. pretiosum was also found to be directly related to the lineage of this parasitoid and to the host and weather conditions (Inoue and Parra, 1998; Faria et al., 2000; Pratissoli and Parra, 2000; 2001; Pratissoli et al., 2004b).

Total parasitism per $T$. pretiosum female varied with temperature showing higher values at $25^{\circ} \mathrm{C}$, and similar ones at the other temperatures with 37.61 eggs of $S$. cerealella parasitized per female of this parasitoid at $25^{\circ} \mathrm{C}$.

Parasitism of $T$. acacioi was also affected by temperature with lower values at $35^{\circ} \mathrm{C}$ and higher values at $25^{\circ} \mathrm{C}$ and $30^{\circ} \mathrm{C}$ when it reached 44.7 and 42.84 eggs of $S$. cerealella parasitized per female, respectively. Lowest parasitism rate of $T$. pretiosum and $T$. acacioi in eggs of $S$. cerealella was registered at 20 and $35^{\circ} \mathrm{C}$, respectively (Table $1)$. 

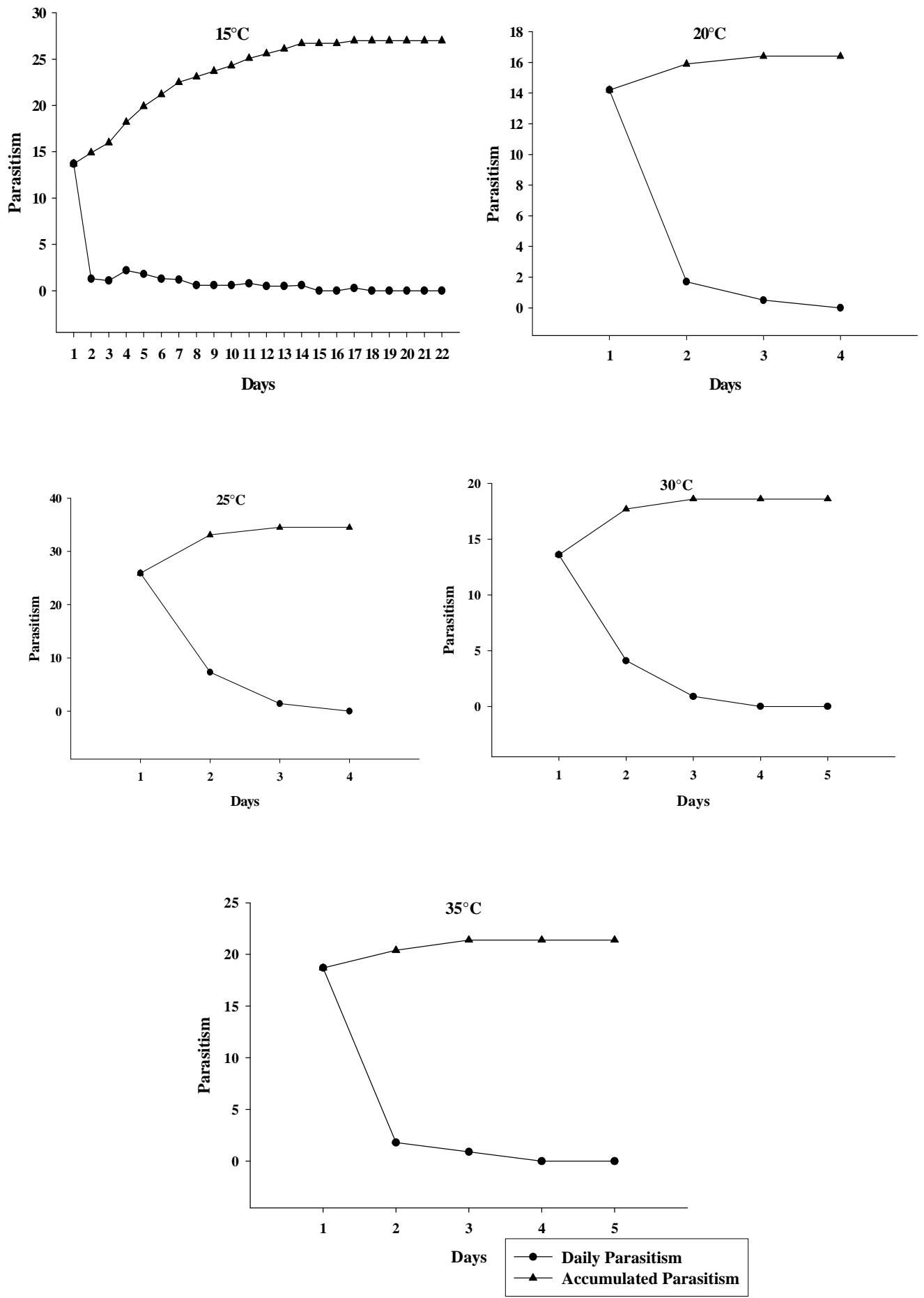

Figure 1 - Daily and accumulated parasitism of Trichogramma pretiosum (Hymenoptera: Trichogrammatidae) in eggs of Sitotroga cerealella (Lepidoptera: Gelechiidae) at different temperatures, RH $70 \pm 10 \%$ and 14 h photophase. 

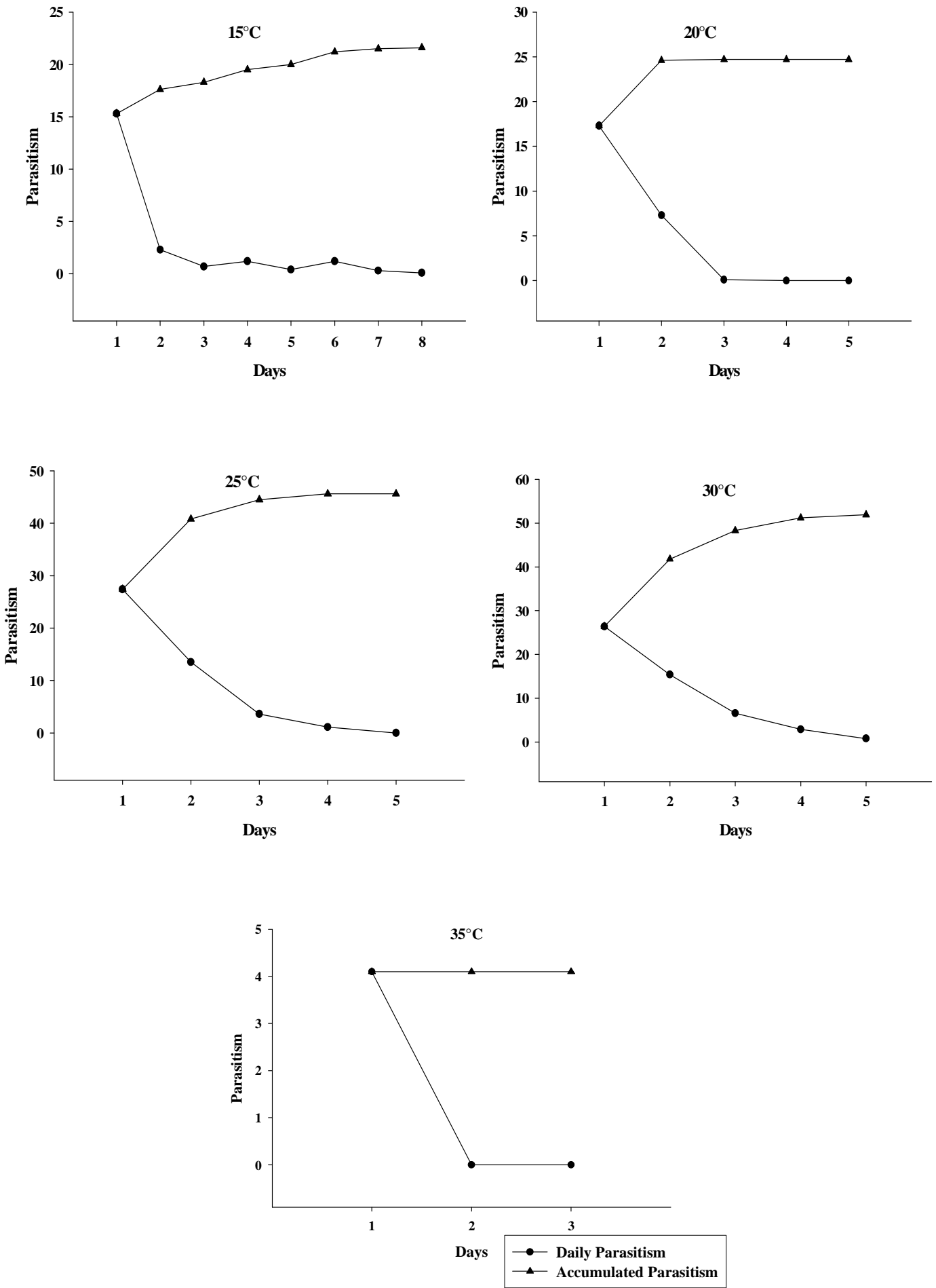

Figure 2 - Daily and accumulated parasitism of Trichogramma acacioi (Hymenoptera: Trichogrammatidae) in eggs of Sitotroga cerealella (Lepidoptera: Gelechiidae) at different temperatures, RH $70 \pm 10 \%$ and 14 h photophase. 
Table 1 - Average number ( \pm standard error of the mean) of parasitized eggs of Sitotroga cerealella (Lepidoptera: Gelechiidae) per female of Trichogramma at different temperatures, RH $70 \pm 10 \%$ and 14h photophase.

\begin{tabular}{ccc}
\hline Temperature $\left({ }^{\circ} \mathbf{C}\right)$ & Trichogramma pretiosum & Trichogramma acacioi \\
\hline 15 & $25.6 \pm 2.39 \mathrm{~b}$ & $23.9 \pm 0,35 \mathrm{~b}$ \\
20 & $19.0 \pm 1.09 \mathrm{~b}$ & $24.4 \pm 0,68 \mathrm{~b}$ \\
25 & $37.6 \pm 1.03 \mathrm{a}$ & $44.7 \pm 0,47 \mathrm{a}$ \\
30 & $21.2 \pm 1.13 \mathrm{~b}$ & $42.8 \pm 0,54 \mathrm{a}$ \\
35 & $23.1 \pm 1.22 \mathrm{~b}$ & $6.3 \pm 0,50 \mathrm{c}$ \\
\hline
\end{tabular}

Means followed by the same letter, in each column, do not differ between themselves by the test of Tukey at 5\% probability level.

Temperatures below $18^{\circ} \mathrm{C}$ can negativelly affect the parasitism capacity of Trichogramma because they are near to the thermic inferior threshold of these parasitoids (Pereira et al., 2004; Pratissoli et al., 2004a; b).

Parasitism rate of $T$. acacioi showed that this species could be negatively affected by temperature of $35^{\circ} \mathrm{C}$ or higher and this could decrease its efficiency in the field conditions during natural and applied biological control. It would be necessary to be consider that the impact of temperature on parasitism rate of $T$. pretiosum and $T$. acacio $i$ were affected by rearing technique, number of generations in laboratory and by kairomones present (Hansen and Jensen, 2002; Pratissoli et al., 2004a; Oliveira et al., 2005).

\section{CONCLUSIONS}

T. pretiosum adapted to $S$. cerealella at $25^{\circ} \mathrm{C}$ and T. acacioi at 25 and $30^{\circ} \mathrm{C}$ when they showed higher parasitism rates. T. pretiosum and $T$. acacioi have potential to be used in biological control programs of $N$. panacea.

\section{RESUMO}

O objetivo deste trabalho foi estudar a capacidade de parasitismo de Trichogramma pretiosum Riley e de Trichogramma acacioi Brun, Moraes and Soares (Hymenoptera: Trichogrammatidae) em ovos do hospedeiro alternativo Sitotroga cerealella (Olivier) (Lepidoptera: Gelechiidae), visando o uso desses inimigos naturais em programas de controle biológico da praga do abacateiro Nipteria panacea Tierry-Mieg (Lepidoptera: Geometridae). O ritmo de parasitismo de $T$. acacioi e $T$. pretiosum variou com a temperatura, sendo maior nas primeiras 24 horas de vida desses parasitóides. Além disso, o período de parasitismo foi maior para essas duas espécies de parasitóides na menor temperatura, enquanto o parasitismo total por fêmea variou com a temperatura.

\section{REFERENCES}

Faria, A. F.; Torres, J. B.; Farias, A .M. I. (2000), Resposta funcional de Trichogramma pretiosum Riley (Hym.: Trichogrammatidae) parasitando ovos de Tuta absoluta Meyrick (Lep.: Gelechiidae): Efeito da idade do hospedeiro. Anais da Sociedade Entomológica do Brasil, 29, 85-93.

Hansen, L. S.; Jensen, K. M. V. (2002), Effect of temperature on parsitism and host-feeding of Trichogramma turkestanica (Hymenoptera: Trichogrammatidae) on Ephestia kuehniella (Lepidoptera: Pyralidae). Journal of Economic Entomology, 95, 50-56.

Inoue, M. S. R.; Parra, J. R. P. (1998), Efeito da temperatura no parasitismo de Trichogramma pretiosum Riley, 1879 sobre ovos de Sitotroga cerealella (Olivier, 1819). Scientia Agrícola, 55, 222226.

Maceda, A.; Hohmann, C. L.; Santos, H. R. (2003), Temperature effectes on Trichogramma pretiosum Riley and Trichogrammatoidea annulata De Santis. Brazilian Archives of Biology and Technology, 46, 27-32.

Oliveira, H. N.; Zanuncio, J. C.; Pratissoli, D.; Cruz, I. (2000), Parasitism rate and viability of Trichogramma maxacalii (Hym.: Trichogrammatidae), parasitoid of the Eucalyptus defoliator Euselasia apisaon (Lep.: Riodinidae), on eggs of Anagasta kuehniella (Lep.: Pyralidae). Forest Ecology and Management, 130, 1-6.

Oliveira, H. N.; Colombi, C. A.; Pratissoli, D.; Pedruzzi, E. P.; Dalvi, L. P. (2005), Capacidade de parasitismo de Trichogramma exiguum Pinto and Platner, 1978 (Hymenoptera: Trichogrammatidae) 
criado em dois hospedeiros por diversas gerações. Ciência e Agrotecnologia, 29, 284-288.

Oliveira, H. N.; Pratissoli, D.; Zanuncio, J.C.; Serrão, J.E. (2003), Influence of the age of Oxydia vesulia eggs on parasitism by Trichogramma maxacalii. Pesquisa Agropecuária Brasileira 38, 551-554.

Pereira, F. F.; Barros, R.; Pratissoli, D.; Parra, J. R. P. (2004), Biologia e exigências térmicas de Trichogramma pretisoum Riley e T. exigumm Pinto and Platner (Hymenoptera: Trichogrammatidae) criados em ovos de Plutella xylostella (L.) (Lepidoptera: Plutellidae). Neotropical Entomology, 33, 231-236.

Pratissoli, D.; Fornazier, M. J. (1999), Ocorrência de Trichogramma acacioi Brun, Moraes and Soares (Hym.: Trichogrammatidae) em ovos de Nipteria panacea Thierry-Mieg (Lep.: Geometridae), um geometrídeo desfolhador do abacateiro. Anais da Sociedade Entomológica do Brasil, 28, 347-349.

Pratissoli, D.; Parra, J. R. P. (2000), Fertility life table of Trichogramma pretiosum (Hym.: Trichogrammatidae) in eggs of Tuta absoluta and Phthorimaea operculella (Lep.: Gelechiidae) at different temperatures. Journal of Applied Entomology, 124, 339-342.

Pratissoli, D.; Parra, J. R. P. (2001), Seleção de linhagens de Trichogramma pretiosum (Hym.: Trichogrammatidae) para o controle das traças Tuta absoluta e Phthorimaea operculella (Lep.: Gelechiidae). Neotropical Entomology, 30, 277-282.

Pratissoli, D.; Pereira, F. F.; Barros, R.; Parra, J. R. P.; Pereira, C. L. T. (2004a), Parasitismo de Trichogramma pretiosum em ovos da traça-dascrucíferas sob diferentes temperaturas. Horticultura Brasileira, 22, 754-757.

Pratissoli, D.; Zanuncio, J. C.; Vianna, U. R.; Andrade, J. S.; Guimarães, E. M.; Espindula, M. C. (2004b), Fertility life table of Trichogramma pretiosum and Trichogramma acacioi on eggs of Anagasta kuehniella at different temperatures. Pesquisa Agropecuária Brasileira, 39, 193-196.
Pratissoli, D.; Oliveira, H. N.; Gonçalves, J. R.; Zanuncio, J.C.; Holtz, A. M. (2004c). Changes in biological characteristics of Trichogramma pretiosum (Hym.: Trichogrammatidae) reared on eggs of Alabama kuehniella (Lep.: Pyralidae) for 23 generations. Biocontrol Science and Technology, 14, 313-319.

Pratissoli, D,; Fernandes, O. A.; Zanuncio, J. C.; Pastori, P.L. (2004d). Fertlity life table of Trichogramma pretiosum and Trichogramma acacioi (Hymenoptera: Trichogrammatidae) on Sitotroga cereallela (Lepidoptera: Gelechiidae) eggs at different constant temperatures. Annals of the Entomological Society of America, 97, 729-731.

Pratissoli D.; Zanuncio J. C.; Vianna U. R.; Andrade J. S.; Pinon T.B.M. (2005a), Biological characteristics of Trichogramma pretiosum and Trichogramma acacioi (Hym: Trichogrammatidae), parasitoids of the avocado defoliator Nipteria panacea (Lep.: Geometridae), on eggs of Anagasta kuehniella (Lep.: Pyralidae). Brazilian Archives of Biology and Technology, 48, 7-13.

Pratissoli, D.; Zanuncio J.C.; Vianna U.R.; Andrade J.S.; Pinon T.B.M.; Andrade G.S. (2005b), Thermal requirements of Trichogramma pretiosum and Trichogramma acacioi (Hym: Trichogrammatidae), parasitoids of the avocado defoliator Nipteria panacea (Lep: Geometridae), in eggs of two alternative hosts. Brazilian Archives of Biology and Technology, 48, 523-529.

Soares, M.A.; Leite G.L.D.; Zanuncio J.C.; Rocha S.L.; de Sá V.G.M.; Serrão J.E. (2007), Flight capacity, parasitism and emergence of five Trichogramma (Hymenoptera: Trichogrammatidae) species from forest areas in Brazil. Phytoparasitica, 35, 314-318.
Received: March 23, 2006; Revised: August 28, 2007; Accepted: August 04, 2008. 